\title{
Searching for the Africa-Eurasia Miocene boundary offshore western Algeria (MARADJA'03 cruise)
}

\section{Anne Domzig ${ }^{a}$, Karim Yelles ${ }^{b}$, Charlotte Le Roy $^{c}$, Jacques Déverchère ${ }^{a}$, Jean-Pierre Bouillin ${ }^{d}$, Rabah Bracène ${ }^{\mathrm{e}}$, Bernard Mercier de Lépinay ${ }^{\mathrm{f}}$, Pascal Le Roy ${ }^{\mathrm{a}}$, Eric Calais ${ }^{\mathrm{g}}$, Abdelaziz Kherroubic, Virginie Gaullier $^{h}$, Bruno Savoye ${ }^{i}$ and Henri Pauc ${ }^{h}$}

\author{
«"Domaines océaniques »-IUEM, UMR6538, université de Bretagne occidentale, place Nicolas-Copernic, 29280 \\ Plouzané, France \\ ${ }^{\mathrm{b}}$ Centre de recherche en astronomie, astrophysique et géophysique, BP 63, Bouzareah, Algeria \\ ${ }^{\mathrm{C} C}$ Chaire de géodynamique, Collège de France, Europôle de l'Arbois, bât. Le Trocadéro, aile sud, BP 80, 13545 \\ Aix-en-Provence, France \\ dLaboratoire de géodynamique des chaînes alpines (UMR 5025), université Joseph-Fourier, Grenoble-1, Maison \\ des Géosciences, 1381, rue de la Piscine, domaine universitaire, 38400 Saint-Martin-d'Hères, France \\ eSonatrach Exploration, av. du 1er-Novembre, Boumerdès, Algeria \\ fGéosciences Azur, UMR CNRS 6526, 250, rue Albert-Einstein, bât. 4, 06560 Valbonne, France \\ ${ }^{9}$ Purdue University, 401 South Grant Street, West Lafayette, IN 47907-2024, USA \\ hLEGEM, 52, av. Paul-Alduy, 66860 Perpignan cedex, France \\ 'IFREMER, DRO-Géosciences marines, BP 70, 29280 Plouzané cedex, France
}

*: Corresponding author : anne.domzig@sdt.univ-brest.fr

\begin{abstract}
We present new results from the MARADJA'03 cruise depicting the geological structures offshore central and western Algeria. Using swath bathymetry and seismic reflection data, we map and discuss the offshore limits of the Internal Zones corresponding to relics of the AlKaPeCa domain that drifted and collided the African plate during the Miocene. We identify large reverse faults and folds that reactivate part of these limits and are still active today. The morphology of the westernmost NE-SW margin suggests a former strike-slip activity accommodating a westward block translation responsible for the shift of the Internal Zones towards the Moroccan Rif.
\end{abstract}

Keywords: Algerian margin; Internal Zones; Neotectonics; Tectonic evolution of the Mediterranean; Swath bathymetry; Seismic reflection

Résumé: Nous présentons les résultats récents de la campagne MARADJA'03, qui visent à mettre en évidence les structures géologiques dans le domaine marin au nord-ouest de l'Algérie. Grâce aux données de bathymétrie multifaisceau et de sismique réflexion, nous cartographions et discutons les limites en mer des Zones internes correspondant aux reliques du domaine AlKaPeCa qui a dérivé, puis est entré en collision avec la plaque africaine au Miocène. De grandes failles inverses et plis, actifs dans le champ de contrainte actuel, réactivent certaines de ces limites. La marge ouestalgérienne, orientée $\mathrm{NE}_{i} \mathrm{SW}$, indique la présence d'une ancienne activité en décrochement ayant accommodé la translation des Zones internes vers l'ouest.

Mots-clés: Néotectonique, Évolution tectonique du Bassin méditerranéen, Bathymétrie multifaisceau, Sismique réflexion, Marge Algérienne, Zones Internes 


\section{Introduction}

Northern Africa is bounded by an Alpine-type orogen resulting from the subduction and closure of the Tethyan Ocean and from the interaction between the European and African plates [7]. This arcuate, almost continuous foldand-thrust belt surrounds back-arc basins induced by the lateral development of two arcs (Gibraltar to the west, Calabria to the east). This back-arc extension started around 30-35 Ma ago [29,34]. From the Early Miocene, extension on the upper (European) plate resulted into the dispersal of the main parts of the Internal Zones of the belt, formerly belonging to the so called AlKaPeCa domain (Al: Alboran, Ka: Kabylies, Pe: Peloritan, Ca: Calabria; [14]). Whereas the AlKaPeCa represents generally the forearc and accretionary prism separated from the European plate (together with Balearic, Corsica and Sardinia blocks), the Algerian and Alboran basins [7,20] are often interpreted as back-arc basins resulting from the subduction rollback towards the south, and later towards the west (e.g., [37] and references therein). The subduction is assumed to begin at $\sim 16 \mathrm{Ma}$ [39] and to be still active in Calabria, but also beneath Alboran [30]; however, this timing and the present-day rollback effect are debated. Although there is a general agreement to consider that subduction has been the main driving mechanism controlling the evolution of extensional basins and orogenic arcs of the Western Mediterranean, several important questions remain open: (1) palinspastic restorations of the AlKaPeCa domain (e.g., [29,39,43]) suffer important limitations and differences owing to the poor control on the structural framework offshore; (2) it is unclear whether the segmentation of the internal massifs along the coast of Africa (Fig. 1) results from the late deformation of a transform-type palaeomargin, or is instead inherited from the Tethyan rifting [13]; (3) the study area is part of a wide zone of deformation reactivated under the present-day compressional stress field, but the amount, timing and style of faulting offshore, as well as the onshore-offshore partitioning of deformation, are unknown, although this area is predicted to undergo the highest fault slip rates in the Ibero-Maghrebian region [46] and has recently experienced a large-magnitude earthquake located offshore [8,22].

In this paper, we aim at bringing new insights into the space and time evolution of the scattered relics of the Internal Zones of the Maghrebian belt of central and western Algeria, and into its tectonic behaviour as part of the Africa-Europe present-day plate boundary. We will first attempt to define at best the limits of segments of Internal Zones offshore, then to characterize the tectonic structures responsible for their setting, and finally to identify those that are still active.

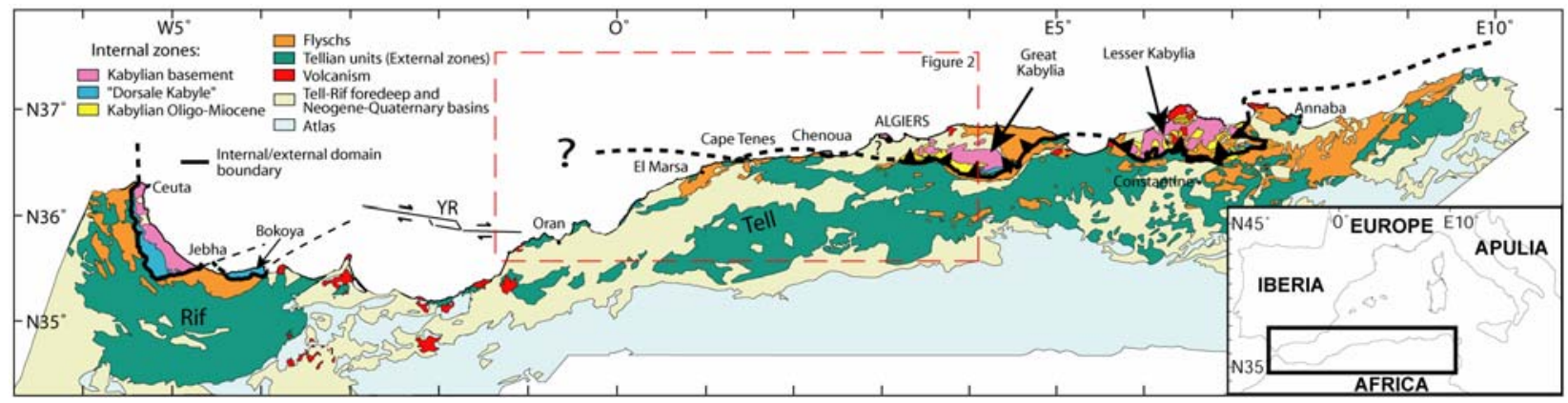

Fig. 1. Geological map of northern Africa, modified from [55]. YR: Yusuf ridge surrounded by the Yusuf fault (location from [20]). The black thick line represents the limit between the Internal and External domains as it was known before this study [33]. See text for explanations.

Fig. 1. Carte géologique du Nord de l’Afrique, modifiée d'après [55]. YR : Ride de Yusuf bordée par la faille de Yusuf (position d'après [20]). La ligne noire épaisse représente la limite entre les domaines interne et externe en l'état des connaissances avant cette étude [33]. Voir explications dans le texte.

\section{Geological setting}

Northern Algeria displays a complex geological setting (Fig. 1). It is mainly made of a segment of the Alpine belt that runs from Gibraltar to Calabria. In Algeria, the main units of this belt, also called Maghrebides [5], have been described by Durand-Delga [24, 25] and Wildi [55]. In the south, the External Zones, also called the Tellian zones [55], have a width of a hundred kilometers. They are characterized by south- or southeast-verging Miocene folds and thrusts. The Tellian zones overthrust the Atlas foreland. Further north, two successive domains are overthrusting the External Zones from south to north, respectively: (1) the flyschs units (Massylian, Mauretanian, and Numidian), 
corresponding to sediments deposited in the Maghrebian Tethys that was later on subducted [12,18], and (2) the Internal Zones of the belt, made of an Hercynian or older basement and its sedimentary cover, the so-called 'Dorsale calcaire' [24]. Internal Zones form discontinuous massifs spread along the coast of central Algeria, namely from east to west: Lesser Kabylia, Great Kabylia, Algiers, Chenoua, and Cape Tenes Massifs (Fig. 1), from east to west. About $400 \mathrm{~km}$ west of Cape Tenes, they outcrop again in Morocco, in the Bokoya Massif and between Jebha and Ceuta (Fig. 1). Although the exact palaeogeography of these massifs within the AlKaPeCa domain is poorly constrained (see discussions in [12,29,39]) and part of the Tethyan ocean may have separated the AlKaPeCa from Europe (see discussion in [43], and [19]), we will assume here that they initially belonged to the European side of the Tethys, in a forearc position, close to the Balearic islands and Sardinia. The AlKaPeCa blocks separated from the European plate at the opening of the Algero-Provençal back-arc basin (Early to Middle Miocene, e.g., [17]), then drifted to the south-east, and began to collide the African passive margin between 18-15 Ma ago ([37] and [27], respectively), possibly followed by a $>560-\mathrm{km}$ westward migration of the Gibraltar Arc after $~ 16$ Ma [39]. However, the ages of these events still remain controversial, and the way the tectonic evolution of the area occurred is also highly debated. For instance, some palaeostresses reconstructions based on microfractures analysis also led to propose a major distensive period from Late Oligocene to Middle Miocene [2,3]. Other debates concern the large massifs of Kabylies, which are assumed to have undergone either an early frontal, north-south ([17,39] and references therein), or oblique, NW-SE [27,29] collision. Furthermore, large strike-slip zones [38] are believed to have segmented the Internal Zones and are supposed to extend offshore, but whether they are inherited from the palaeogeography of the northern palaeomargin of the Maghrebian Tethys [13] or whether they result from the development of a bookshelf faulting system in the Plio-Quaternary stress field [45], is unclear, due to the lack of accurate marine data.

In the following, we will assume a simplified evolution from a pre-Miocene period, where the strike-slip activity was dominant, and a post-Miocene one, characterized by compression, starting at around $8 \mathrm{Ma}$ ago [6]. Nowadays, the convergence of the African plate towards the Eurasian plate is $~ 5.1 \mathrm{~mm}$ yr- 1 in a $\mathrm{N} 60^{\circ} \mathrm{W}$ direction [47] at the longitude of Algiers. Since the Quaternary, compressional structures on-land provide an approximate shortening rate of 1-2.3 mm yr-1 for the Rif and Tell domains [42]. Therefore, an important part of the North African deformation (up to 50\%) could be located offshore and further north on-land in the Betics. The May 21, $2003 \mathrm{Mw} 6.8$ Boumerdes earthquake [8] has demonstrated the existence of active north-verging structures offshore that are indeed accommodating part of the convergence [21,22]. They also represent an important seismic hazard for the coastal cities of Algeria, including Algiers. Several other seismicity patterns further support this assessment (e.g., [57]). These reverse faults appear to have a vergence opposite to most of those of the main Miocene thrusts of the TellAtlas. This pattern may arise from a major change in the tectonic style of the region through the reactivation and inversion of previous tectonic structures of the Maghrebian belt and Mediterranean margins in the present-day NWSE compressional system [53]. Indeed, stress conditions in the region have not always been steady: important changes of the tectonic regime occurred from Late Cretaceous to Early Oligocene [48,51], and the African plate motion varied during the last few Ma [16, 40]. Therefore, from our new dataset, we also aim at clarifying whether the current structural pattern is influenced by older (pre-Miocene and Miocene) inherited structures.

\section{MARADJA cruise data}

The MARADJA cruise took place on board the R/V Le Suroît (IFREMER) from 21 August to 18 September 2003. It has been scheduled in order to identify accurately the bathymetry and offshore structures from Oran to Dellys (Fig. 2). The area covered by the cruise was divided into three zones: from Dellys to Mt Chenoua, from Mt Chenoua to El Marsa, and finally from El Marsa to Oran (Fig. 2). We gathered more than $5000 \mathrm{~km}$ of seismics and continuous seafloor imagery, along $600 \mathrm{~km}$ of coastline, from Oran, to the west, to Dellys, to the east. The bathymetric and reflectivity data were obtained using a Kongsberg EM300 Simrad multibeam echosounder (and EM1000 for the continental platform).

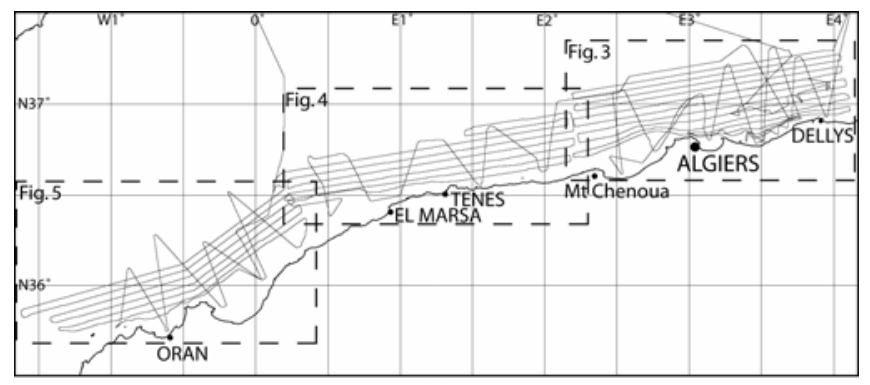

Fig. 2. Location of the ship tracks acquired during the MARADJA'2003 cruise.

Fig. 2. Plan de position de la campagne Maradja'2003. 
Simrad EM300 is a 32-kHz multibeam system that allows for overall swath coverage of $\sim 6$ times water depth, increasing with depth to a maximum width of $5000 \mathrm{~m}$ at $1000 \mathrm{~m}$. We have obtained a resolution of $15 \times 35 \mathrm{~m}$ at 1000-m depth with a vertical accuracy from $2 \mathrm{~m}$ (central beam) to $10 \mathrm{~m}$ (lateral beam). Sound speed is estimated from regularly spaced velocity profiles for accurate depth conversions. The bathymetric and backscattering data have been processed with the CARAIBES ${ }^{\circledR}$ software (IFREMER). We produced a digital elevation model for the seafloor topography, with a resolution of $50 \mathrm{~m}$ for the regions of Oran and Tenes, and 25-35 m (depending on depth) for the Algiers zone. Two types of seismic reflection data were obtained, i.e. 6- or 24-channel seismics (4169 and $802 \mathrm{~km}$ of sections, respectively). The SU (Seismic Unix) CWP/SU software (Center of Wave Phenomena, Colorado School of Mines) was used for the stack and migration of the seismic data. In addition, a $2-5-\mathrm{kHz}$ CHIRP sonar was used during the entire cruise, as well as a gravimeter and a magnetometer, and eight cores (56 $\mathrm{m}$ in total) were successfully obtained by a Küllenberg piston corer. For the purpose of studying the morphology of the seafloor and the structure of the margin, we will mostly use the results obtained from the bathymetric and seismic data, and describe the margin from east to west by dividing it into 3 main zones (Algiers, Tenes, and Oran, Fig. 2).

\section{Algiers zone}

Between Algiers and Dellys (Fig. 3), the continental platform is narrow (especially close to the Algiers massif where the slope is as steep as 15\%), except in the bays, where it widens. Along the margin, our new bathymetric map reveals numerous canyons, generally presenting a network of tributaries. The two main ones are the Algiers canyon and the Dellys canyon [10]. The first one is a meandering canyon, formerly draining the the Isser River, according to the palaeo-location of the river [10], and presents signs of deviations (Fig. 3). The second one is rather straight, with several tributaries, and probably drains the Sebaou River. Some limited areas on the slope present a smoother topography, without any canyons (see s in Fig. 3). The continental slope east of Algiers is strongly irregular, with an intermediate flat of various width and a rather sinuous slope break (east-west, NE-SW and NW-SE segments). In this area, the margin does not exceed $20 \mathrm{~km}$ in width, and is depicting NE-SW slope breaks striking in a N70 ${ }^{\circ}$ mean direction, a direction already known on-land, through folds in Great Kabylia, for example, the ones in the Tizi-Ouzou basin (i.e. [50]). Two different types of slope breaks were identified: a rollover basin on the slope, formed on top of a listric normal fault, and a piggyback basin further down in the deep basin ([22]; Fig. 3), a simple sedimentary filling behind a blind thrust. These slope breaks result mostly from the Plio-Quaternary activity of deeper thrust ramps [22], one of them striking $\sim \mathrm{N} 70^{\circ}$ being assumed to connect at depth to the Boumerdes earthquake rupture (this strike corresponds to the one found by Delouis et al. [21], from seismological and geodetical observations). Folding affects the layers up to the top of the Quaternary layers (Fig. 3, seismic line 1), regardless of salt diapirism effects. We also identify east-west lineaments on the bathymetry in the deep basin. They may underline the presence of tenuous accidents, not necessarily active anymore, along which the salt extruded and formed salt walls (Fig. 3). West of Algiers, the slope changes to a $\mathrm{N} 115^{\circ}$ direction (again, a well known direction in Great Kabylia, [2]) as it encounters a large submarine bank (Khair al Din). As a consequence, the margin width increases up to $45 \mathrm{~km}$ north of Tipaza (Fig. 3).

The Khair al Din bank is an elongated high (500-m depth), previously roughly known (e.g., [38]), overhanging the deep basin as deep as $2700 \mathrm{~m}$. On the eastern flank of the bank, the canyons are narrow, dense and straight, and look more like linear gullies. On its northwestern side, the slope break is striking $N 70^{\circ} \mathrm{E}$ and is very sharp. We identify there a deep-sea fan and an area without canyons, probably smoothed by sedimentary processes like slope instabilities. On the seismic line 2 (Fig. 3), active thrust faulting is suggested by the folding of the Plio-Quaternary sediments and numerous reverse faults distributed above the acoustic basement. In the deep basin, the main features are salt domes organized as walls of several kilometre length. This main change of morphology between the western and eastern sides of Algiers may indicate that the Boumerdes area is composite: Kabylian Oligo-Miocene sediments or Flyschs units and some volcanic deposits can compose it, taking into account the continuity that should exist between known onshore outcrops in the Boumerdes-Dellys area [55] and offshore rocks. Conversely, the Khair al Din bank corresponds to a relic of the Kabylian basement, like the nearby Algiers massif (Fig. 6). The difference of lithology could also explain the difference of drainage pattern and faulting style along this part of the margin (i.e. several successive thrusts striking northeast and southwest across the margin east of Algiers, but only one major north-verging thrust striking $\mathrm{N} 115^{\circ}$ between Chenoua and Algiers).

On the southwestern end of Khair al Din, we identify the prolongation of a major tectonic feature, known onland as the Chenoua anticline. This south-verging thrust fold (Fig. 3, Inset 3) has been seismically activated on both sides of the shoreline during the 29 October 1989 Ms: 6.0 reverse faulting event [41]. Thanks to four seismic lines crossing this structure (Fig. 2), we are able to map for the first time the eastern offshore prolongation of the Chenoua thrust fold (Fig. 3). 
The main thrusts identified offshore the Algiers zone on the slope or in the deep basin (Fig. 3) have a northern vergence, therefore opposite to most tectonic features found inland ([27,52] and references therein). For instance, the Sahel anticline and the Kabylies thrust front are controlled by north-dipping faults (e.g., [11,41]). The offshore thrusts may represent south-dipping backthrusts recently formed (Plio-Quaternary) behind the main south-verging suture south of the Kabylies [22, 52]. It is believed that this suture zone formed at the end of the Kabylian collision with the African plate, during the Miocene. However, the position and geometry of the Sahel and Chenoua folds and thrusts relative to the main active thrust suggest that they represent backthrusts of the main south-dipping thrust found at the foot of the Khair Al Din Bank (Fig. 3).

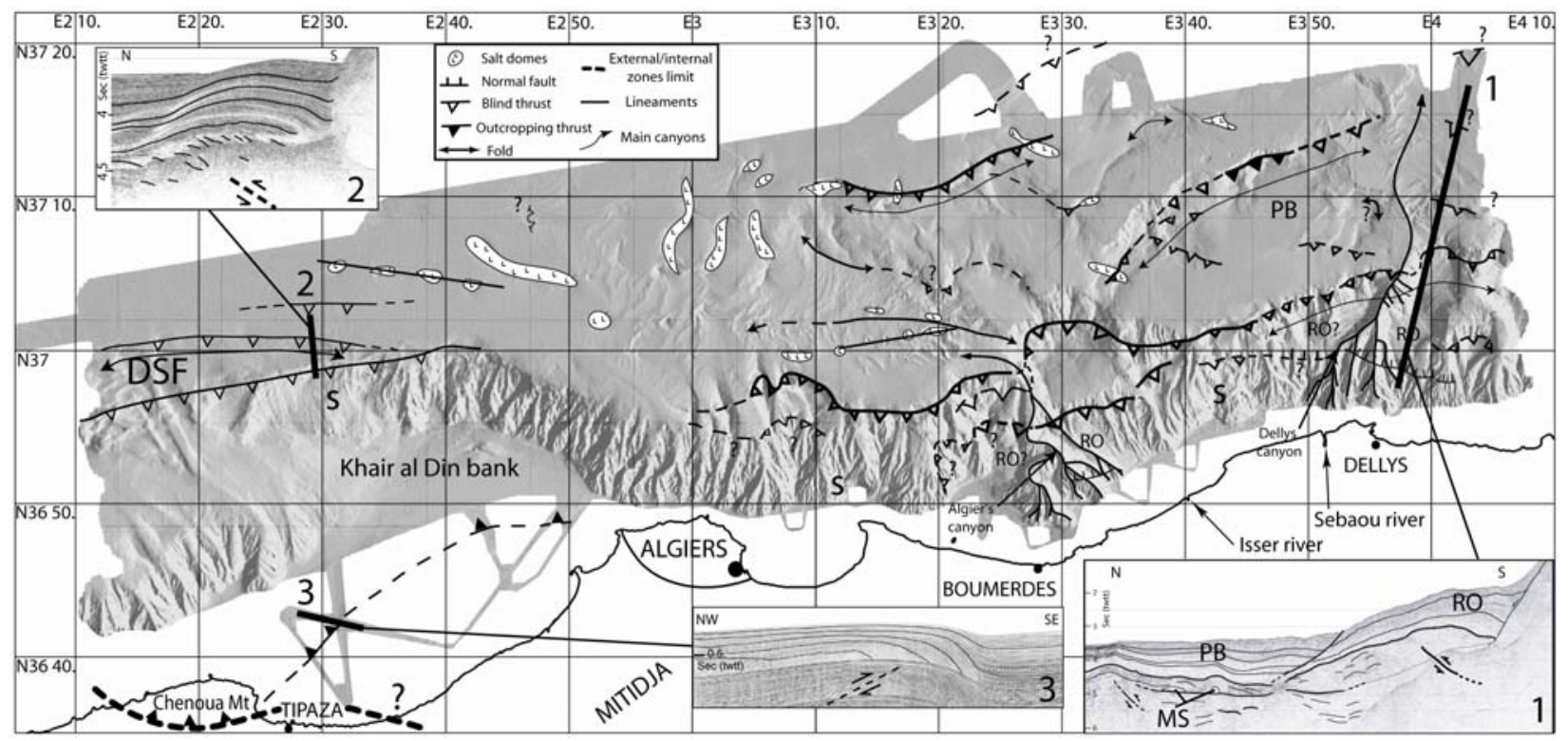

Fig. 3. Shaded bathymetric map (obtained from a 50-m DEM) of the Algiers region with the main geological features identified (salt domes, lineaments, main canyons, normal and thrust faults, and folds). Black thick lines: position of the time-migrated, stacked 6-channel seismic lines (vertical exaggeration: 4). RO: Rollover basin, PB: piggy back basin, MS: Messinian salt, s: areas with a smoother topography and less canyons, DSF: deep-sea fan. Dashed black thick lines: southern limit of the Internal Zones.

Fig. 3. Carte bathymétrique ombrée (obtenue par un MNT au pas de $50 \mathrm{~m}$ ) de la région d'Alger, avec les principales structures géologiques identifiées (dômes de sel, linéaments, canyons principaux, failles normales et inverses, plis). Lignes noires épaisses : position des profils sismiques 6 traces sommés et migrés en temps (exagération verticale $=4$ ). RO : Bassin en rollover, $\mathbf{P B}$ : bassin en piggy-back, MS : sel messinien, $\mathbf{s}:$ zones présentant une topographie plus lissée et moins de canyons, DSF : éventail sous-marin profond. Lignes épaisses en pointillé : limite sud des Zones Internes.

\section{Chenoua-Tenes zone}

This zone is characterized by a linear and east-west oriented continental slope (Fig. 4), which is also quite steep (10\%) compared to other Western Mediterranean margins (e.g., $[1,4,49])$ : in Cape Tenes, the cliffs almost overhang the abyssal plain. On the eastern side of the zone, we observe the westward end of the Khair al Din bank, also called the perched valley of Dahra [26], which progressively deepens along strike, and finally vanishes into the deep basin. This causes a sharp shrinkage of the margin length ( $37 \mathrm{~km}$ at E2 ${ }^{\circ}$ to $20 \mathrm{~km}$ at E1 $\left.{ }^{\circ} 45^{\prime}\right)$. On the bank, the few canyons are shallow, and two large slide areas (Fig. 4) are located on the flanks of the perched valley. It appears that the entire Khair Al Din block is tilted, and that tilting is controlled by a blind thrust in the front, and accommodated by a normal fault in its back (Fig. 4, seismic line 1).

West of this block, the continental shelf is particularly narrow: the margin width changes from only 20 to $40 \mathrm{~km}$ from east to west. The seismic lines offshore Tenes (Fig. 2) depict an acoustically rough basement, very chaotic, sometimes locally folded, on the continental slope (Fig. 4, line 2). The numerous canyons strike generally northsouth and depict linear and narrow paths. Furthermore, the crests between the canyons become sharp and the roughness of the topography increases. We interpret this morphology as an evidence for a resistant lithology. Many of the canyons present short along-strike shifts or steps in their bed topography that underline the presence of east- 
west faults (Fig. 4). On the lower part of the slope, the Pliocene reflectors are tilted towards the north (Fig. 4, seismic line 3). This tilting may be a consequence of several tectonic and or gravity-driven events. Firstly, the salt may have slid downslope: this retreat towards the deep basin could have induced the southward tilting of Plio-Quaternary layers. Secondly, canyon-related sedimentary deposition would have been responsible for the fan architecture of the reflectors. Secondly, the margin has probably been uplifted (as described in the Tenes area [56]), which made the sedimentary layers slide toward the north, and may have triggered the opening of east-west fractures underlined by the east-west lineaments leaving imprints in the sediment layers above the bedrock (Fig. 4, Inset 3). Finally, the tilting of the Plio-Quaternary sediments is not sealed by an unconformity, so that the deformation must still be active. Indeed, a broad zone of north-verging faults and flexures has been predicted offshore along the margin, between El Marsa and Chenoua [56] (Fig. 4).

Finally, northwest of El Marsa, a large deep-sea fan with typical sedimentary waves (e.g., [44]) is found to mark the western end of this part of the margin. It is limited to the south by a linear east-west structure, $\sim 22 \mathrm{~km} \mathrm{long}$, which controls the geometry of the Quaternary deep-sea fan, allowing for the northern levee to become dominant. As shown on the seismic line 4 (Fig. 4), the Plio-Quaternary canyon path lies upon a network of subvertical faults that could be associated with a strike-slip zone. We can follow the canyon almost up to the coast (Inset 5, Fig. 4). Furthermore, we observe a drastic change in the acoustic basement facies below the deep-sea fan, on both sides of the fault system: north of it, we identify a chaotic and highly folded basement (similar to the basement facies found in front of Tenes), whereas to the south the basement is organized as discontinuous, weak reflectors (Inset 4, Fig. 4). This is an indication that the east-west fault zone limits two different geological units: (1) the smooth topography located south of the accident could be the surficial expression of the soft material from the Tellian units; (2) the rough basement, north-east of the accident, could represent the Palaeozoic Kabylian basement or the 'Dorsale kabyle' sediments, composed by carbonates and also found onshore at the southern flank of the Kabylian basement [14].

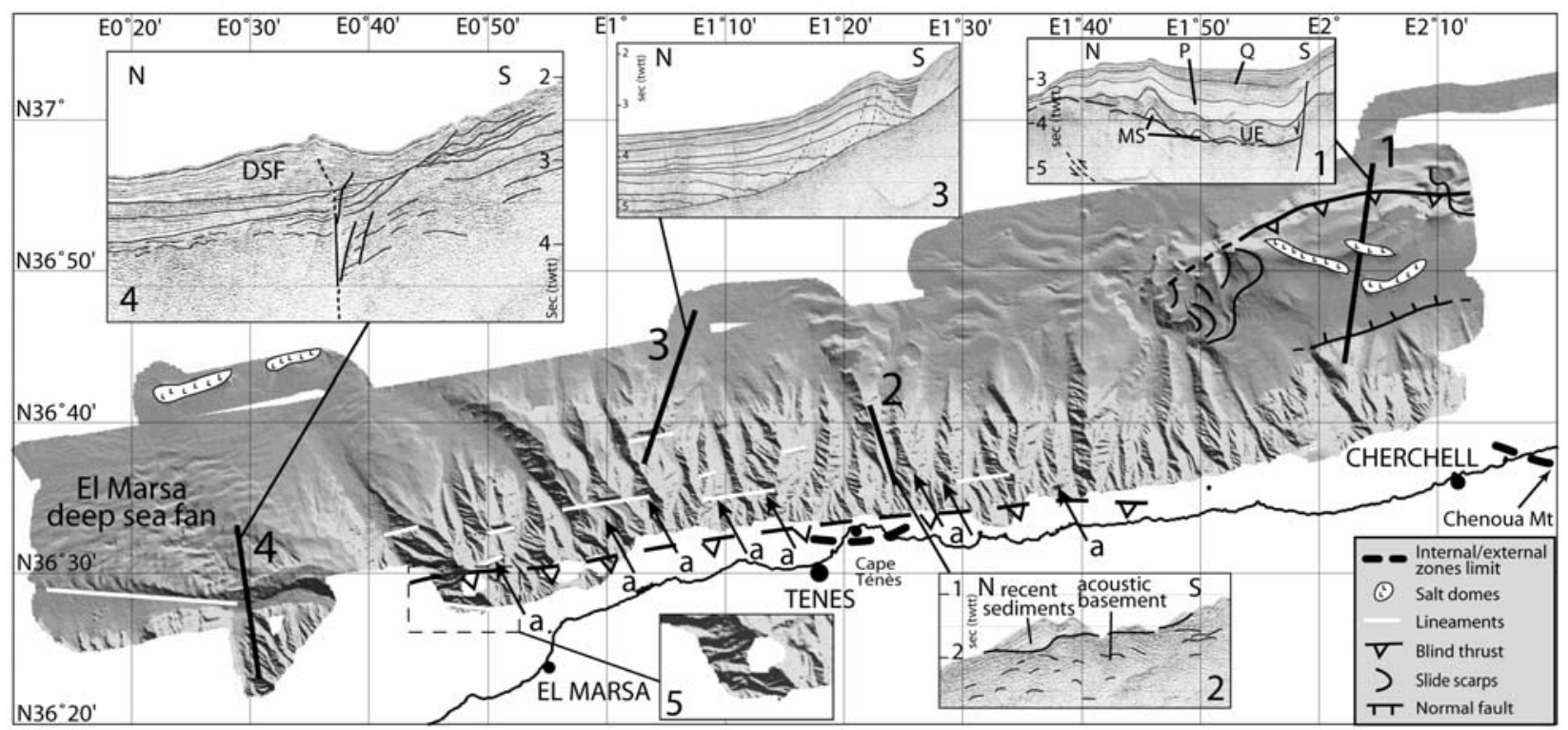

Fig. 4. Shaded bathymetric map (obtained from a 50-m DEM) of the Tenes region with the main geological features identified (salt domes, lineaments, normal and thrust faults, and slide scarps). Black thick lines: position of the time-migrated, stacked 6-channel seismic lines (vertical exaggeration: 4), DSF: deep-sea fan, Q: Quaternary, P: Pliocene, UE: upper evaporites, MS: Messinian salt, a: canyon deviations. Dashed black thick lines: southern limit of the Internal Zones. Dashed thin line: assumed fault zone, modified from [56] and our observations.

Fig. 4. Carte bathymétrique ombrée (obtenue par un MNT au pas de $50 \mathrm{~m}$ ) de la région de Ténès, avec les principales structures géologiques identifiées (dômes de sel, linéaments, failles normales et inverses, et cicatrices d'arrachement). Lignes noires épaisses : position des profils sismiques 6 traces sommés et migrés en temps (exagération verticale $=4$ ). DSF : éventail sous-marin profond, $\mathbf{Q}$ : Quaternaire, $\mathbf{P}$ : Pliocène, UE : évaporites supérieures, MS : sel messinien, a : déviations de canyons. Lignes épaisses en pointillés : limite sud des Zones Internes. Lignes noires fines en pointillés : zone de faille supposée, modifié d'après [56] et nos observations. 


\section{Oran zone}

Further west, south of the previously described east-west accident, in the area extending from Oran to El Marsa (Fig. 5), a striking observation is the change of structural direction, from east-west to NE-SW. The continental platform appears to deepen continuously from Arzew (200 m deep) to north of Mostaganem, where is reaches $800 \mathrm{~m}$ depth, on its edge. It is narrow in front of the capes (less than $10 \mathrm{~km}$ ) and widens in the bays (up to $40 \mathrm{~km}$ ). Between Oran and El Marsa, the continental slope is very steep (10 to 16\%) and remarkably linear and narrow (in the area of Arzew, the bathymetry starts at $200 \mathrm{~m}$ upslope and suddenly falls at $2600-\mathrm{m}$ depth about $10 \mathrm{~km}$ further downslope). It is cut by smooth and shallow canyons perpendicular to the coast, and remains rather linear. According to the smooth topography of the slope, we hypothesize that this part of the margin is made of the same geological units found nearby onland, i.e. the Tellian units composed mostly by soft marls or flyschs nappes [55]. Therefore we propose that we enter here another geological domain belonging to the External Zones.

Between Oran and El Marsa, we observe some lineaments with a N10 ${ }^{\circ}$ trend and, at the foot of the Arzew-El Marsa linear slope, en echelon $\mathrm{N} 45^{\circ}$ trending lineaments. Both families of lineaments are clear on a slope map (Inset 3 , Fig. 5). The $\mathrm{N}^{\circ} 5^{\circ}$ and $\mathrm{N} 10^{\circ}$ trending lineaments show the same right-stepping en echelon segmentation. They could be associated to strike-slip movement. However, we do not see any evidence for active faulting on the seismic lines (Inset 1, Fig. 5, shows very horizontal reflectors, except where the salt forms domes, far in the deep basin) and this area is also seismically almost inactive. So it may have played a role only in the past and could be locked in the present-day stress field. The very linear shape of the margin in this area may be due to a former faulting activity along a palaeotransform margin.

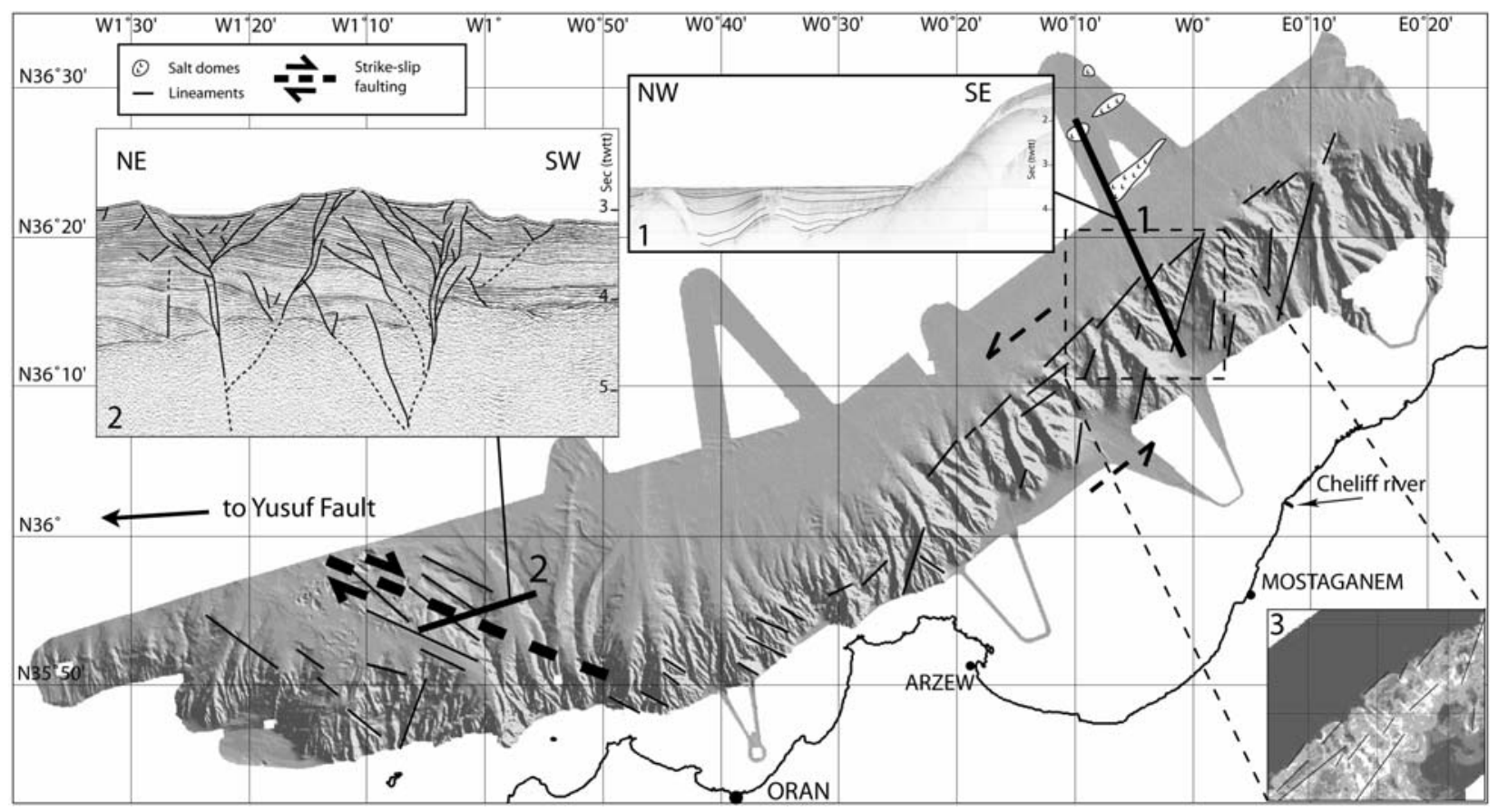

Fig. 5. Shaded bathymetric map (obtained from a 50-m DEM) of the Oran region with the main geological features identified (salt domes, lineaments, and strike-slip fault). Black thick lines: position of the time-migrated, stacked 6- and 24-channel seismic lines, for the seismic lines 2 and 1, respectively (vertical exaggeration: 4). Lower-right corner: slope map calculated from the 50-m DEM (slope increases from dark to white).

Fig. 5. Carte bathymétrique ombrée (obtenue par un MNT au pas de $50 \mathrm{~m}$ ) de la région d'Oran, avec les principales structures géologiques identifiées (dômes de sel, linéaments, failles en décrochement). Lignes noires épaisses : position des profils sismiques 6 traces et 24 traces (profils $\mathbf{2}$ et 1 respectivement) sommés et migrés en temps (exagération verticale $=4$ ). En bas à droite : carte de pentes, calculée à partir du MNT à $50 \mathrm{~m}$ (la pente augmente du foncé au clair).

West of Oran, the margin depicts again a major change in strike and recovers a general east-west direction. Furthermore, variations in the slope morphology might indicate the presence of volcanic material, as it was described onshore in this region and in some offshore samplings [23,36]. West of Oran, on the bathymetry, we observe long 
NW-SE lineaments, with some of them presenting en echelon patterns. The study of our seismic lines shows that each lineament is correlated to a small fault. These faults form a network of fractures typical of flower structures (a negative, symmetric one, and another one, asymmetric). These two structures are probably rooted together on a deeper main fault (Inset 2, Fig. 5). This pattern indicates a dextral strike-slip motion with a normal component, probably corresponding to the eastern end of the Yusuf ridge [20]. Miocene volcanic activity [20,38] also underlines the presence of a faulted zone. Furthermore, there is evidence onland for dextral strike-slip motion [54] exactly in the prolongation of offshore structures.

As a whole, these observations are in agreement with structural observations [20], seismicity pattern and several fault plane solutions of earthquakes [9,31] indicative of a large strike-slip zone west of Oran, associated with the Yusuf ridge [20].

\section{Discussion}

\subsection{Limits of the Internal Zones}

From the observations described in the sections above, we propose a new geological map for the offshore domain (Fig. 6). Although we lack here deep coring, basement samplings and dense seismic reflection data in order to support our hypotheses, we attempt to relate the lithology offshore to the one onshore from the changes of geometry, morphology, bathymetry, roughness and seismic structures reported.

The contact between Internal and External Zones is clearly mapped west of El Marsa, along the east-west accident delimitating the southern end of the El Marsa deep-sea fan (Fig. 6). Elsewhere, we have used several geomorphic markers and changes in the roughness of the bathymetry or seismic facies, together with geological evidence onland, in order to propose a connection of offshore domains either to the Internal Zones, External Zones, or the Algerian 'oceanic-type' crust of the deep basin. However, several limitations and doubts about the basement nature remain, that are discussed hereafter.

\subsubsection{Contact between External and Internal Zones}

Around the longitude $\mathrm{E} 4^{\circ}$, the acoustic basement could be the Kabylian basement covered by the flyschs units that are also present on the southern facing coast. In this case, we cannot define clearly the exact boundaries of the flysch body, because the outcropping sediments are thick layers of Plio-Quaternary deposits, therefore hiding the basement lithology and smoothing the morphology. The same problem occurs between Oran and El Marsa: the flyschs as well as the Tellian units are present onshore between $0^{\circ}$ and $\mathrm{E} 1^{\circ}$, so we can suppose that they extend offshore. They are both made of soft material; therefore, we would need dredgings or corings to be able to distinguish them. Despite all these uncertainties of lithology, we can however say that the Internal Zones are present offshore from the Algiers region to El Marsa. In the Algiers zone, the boundary between Internal and External Zones lies probably below the Mitidja basin [33], whereas in the Tenes region it is probably near the coastline, on the continental shelf, out of our ship tracks. Finally, southwest of the El Marsa deep-sea fan, we enter the External domain.

\subsubsection{Contact between Internal Zones and Neogene oceanic crust}

The deep basin is filled by thick Neogene sediments, and its basement probably corresponds to the oceanic floor of the Algerian basin. From palinspastic reconstructions [29,39], the northern margin of the Internal Zones could be either a passive margin that separated the AlKaPeCa domain from Southern Europe at the first stage of drifting at 23-16 Ma (Kabylies), or a transform margin born during the westwards migration of the Alboran Arc, after 16 Ma. In the Algiers area, the domain at the foot of the margin is called 'transitional zone' [18] and is of unknown origin. We assume here that the continental domain approximately stops at the foot of the slope, therefore we place the northern end of the internal or external domains where the deep basin starts, i.e., in absence of any other constraints, approximately at the isobath $2600 \mathrm{~m}$. We have checked that the northern limit of the internal domain proposed using this criteria is roughly correlated to a major magnetic anomaly [28,39], which is supposed to indicate the transition from continent to oceanic crust (Fig. 6). The magnetic data from Galdeano and Rossignol [28] do not cover the coastal part of the margin, but we have used our preliminary magnetic data to further strengthen the position of the anomalies in the vicinity of the margin. 


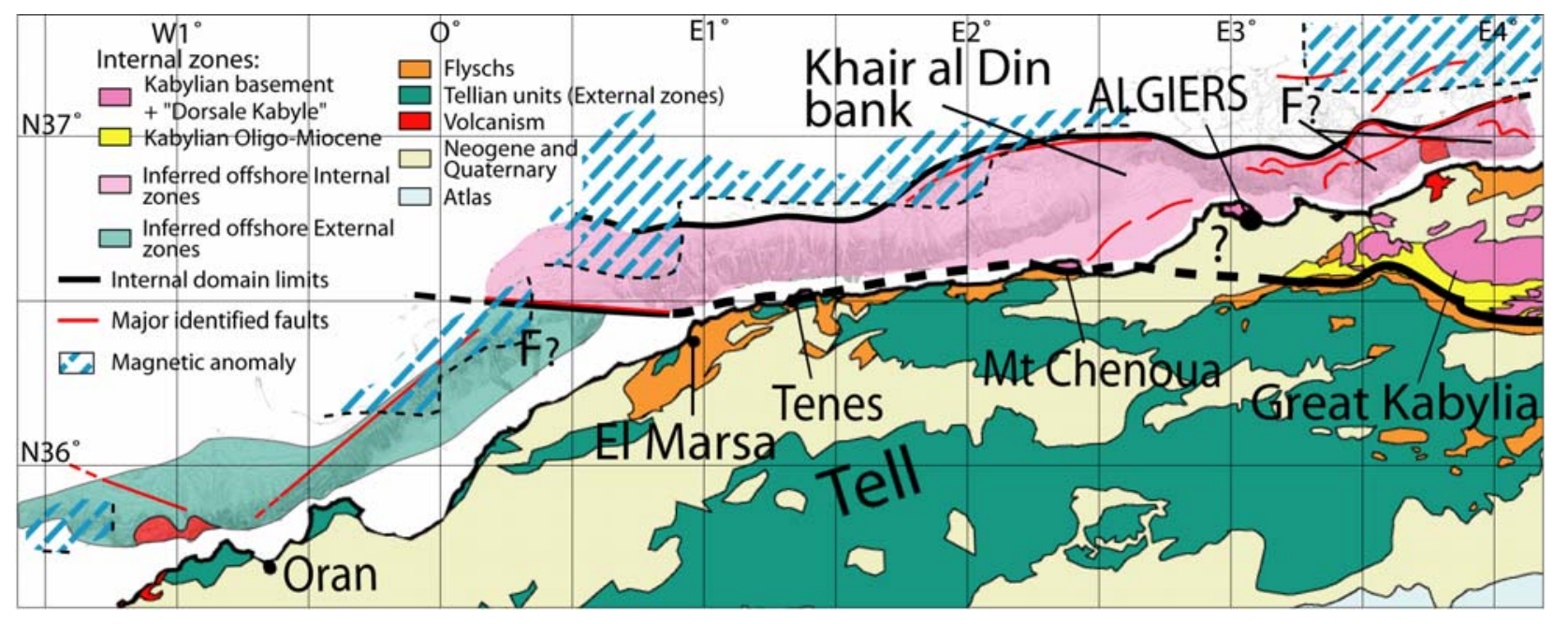

Fig. 6. Geological map of the Oran-Algiers area and limit between the internal and external zones inferred from the offshore observations of this study. East of Algiers, the assumed offshore internal domain could also represent part of flysch units overlying the basement ('F?'), and northeast of Oran, the External domain could also contain flysch units ('F?'), as it is observed on the facing coasts. Hachured lines: main magnetic anomaly after [28] (the dashed black thin lines represent the southern limit of their dataset).

Fig. 6. Carte géologique de la zone entre Oran et Alger montrant la limite entre les zones Externes et Internes déduites des observations en mer de cette étude. À l'est d’Alger, le domaine interne supposé pourrait aussi représenter une partie des unités de flyschs qui recouvrent le socle à terre ( « F ? »), et au nord-est d’Oran, le domaine externe pourrait également contenir des flyschs («F ? »), comme il en existe sur les côtes adjacentes. Hachures : principales anomalies magnétiques d’après [28] (les pointillés fins noirs représentent la limite sud des données).

\subsection{Consequences on the tectonic evolution of northern Algeria}

The Internal Zones appear to be narrow. Firstly, it should be emphasized that they appear to have been deeply eroded, so that only pieces of them are left. Secondly, they look like lenses in map view (two 'boudins' at longitudes $E 0^{\circ}-3^{\circ}$ and $E 3^{\circ}-4^{\circ}$, and one necking level at longitude E3 ${ }^{\circ}$, in our study area). They have been described as 'megaboudins' in the Transmed Atlas [52]. Although preliminary, our observations favour the hypothesis of strikeslip fault systems which may have either originally shifted the northern margin of the Maghrebian Tethys in the Tenes-Algiers zone [13] or have accommodated the westwards migration of the Alboran Arc in the Oran-El Marsa zone, since we have found evidence for palaeo-strike-slip movements, especially in the zone between Arzew and El Marsa (see §5). Whether all the different blocks of the Internal Zones were initially separated, or whether they were torn apart later on, is still questionable. However, strike-slip motions are likely to have played a key role in the margin evolution, considering the numerous indications for transcurrent displacements (en echelon patterns, flower structures, long and parallel lineaments, and steepness of the slope between Arzew and El Marsa).

Several kinematic models of the westernmost Mediterranean propose a more or less north-south collision of the AlKaPeCa blocks $[17,23,27,43]$. However, the trajectories are still poorly known and were probably complex - for instance, oblique with a clockwise rotation. Furthermore, a diachrony of collision from east to west is often suggested [29,39], which could explain the northeast-striking margin between Oran and E0¹0' as a transform-type margin born after 16 Ma to accommodate the westward migration of the eastern Alboran block.

The escarpments near the coast are rarely described, except at the foot of the slope west of Oran, recognized as the continuation of the Yusuf dextral strike-slip fault [38,45] (Fig. 5), and at the Thenia scarp, between Algiers and Boumerdes [10] (Fig. 3). NW-SE lineaments and vertical accidents (affecting Neogene sediments) in the seismic lines (see §5) clearly favour the continuity of the Yusuf ridge towards the east. We did not detect similar indications in the continuation of the Thenia fault: however, the margin east of the Khair-Al-Din bank depicts the same strike, suggesting a genetic link between these structures. Considering the existence of a large strike-slip corridor controlled mainly by the Nekor and Jebha faults in Morocco (e.g., [35,43]), we propose that a system of relay worked offshore during the Miocene, the strike-slip movement occurring first on the Yusuf fault, and later on a system of SW-NE faults located near the Oranese margin accommodating the westward escape of the East Alboran block. 


\subsection{Reactivation of structures}

The seismicity from the last three decades shows great changes from east (Algiers zone) to west (Oran zone) (e.g., [9]). The Algiers area is by far the most active. Nowadays, the major active faults depict compressional focal mechanisms, and these are a potential hazard for the coastal cities of Algeria. Only the SW-NE striking structures seem active in the present-day stress field, whereas NW-SE structures are apparently not. These latter ones were probably active under a different stress field. Some authors suggest the presence of active strike-slip faults along the Algerian margin [38,42]. However, according to the recent focal mechanisms and seismicity distribution, it appears that these faults have no clear activity today. They may have played an important role in the past (at least before the Quaternary, but probably before the beginning of the compressive stage of the margin, during the Miocene), and some of them favourably oriented could be reactivated as thrust faults in the present-day stress field. This could be the case of the Khair al Din reverse fault (Fig. 3). Conversely, the series of north-verging thrusts offshore Boumerdes are probably neoformed Plio-Quaternary structures [52], and correspond to the beginning of the margin inversion [22]. The Tenes area is slightly seismogenic, with small earthquakes that appear spread offshore, according to the NEIC catalogue of earthquakes from 1973 to present. Most large earthquakes occurred inland, and are associated to Tellian folds and thrusts, as for instance the Mw 7.3 El Asnam 1980 event.

Some other examples of more limited active features are found offshore. The fold at the eastern continuation of the Chenoua anticline is also active (Fig. 3), as shown by the Chenoua 1989 earthquake [41]. The accident limiting the South of the El Marsa deep-sea fan could be active too, since it is very linear and fresh: however, the sedimentary dynamics combined with an inherited structure could also explain this feature. By contrast, the offshore area between Oran and El Marsa is almost aseismic, and the bathymetry and the seismic lines did not show any sign of significant tectonic activity. However, the Palomares margin, conjugate of this part of the Algerian margin, depicts an active dextral strike-slip feature called the Carboneras-Palomares fault (e.g., [15, 32]). Both margins could correspond to a former large strike-slip corridor, which has accommodated the westwards motion of the East Alboran block [35,39]. These contrasting patterns of activity may arise from strain partitioning between the Betics and the Atlas domain: the southern part of the system could accommodate a part of the NW-SE component of convergence onland, in the Tellian folds and thrusts (e.g., Cheliff basin), whereas the inherited strike-slip system at the foot of the continental slope does not display a favourable dip to allow for a compressional reactivation.

\section{Conclusion and perspectives}

The Maradja'2003 cruise provides for the first time a detailed morphostructural database of the $\sim 500-\mathrm{km}$ long Algerian margin from Dellys to Oran. From a preliminary interpretation of the new bathymetric maps and seismic sections obtained, we identify several tectonic features related to the main geological suture of North Africa in the Miocene (the 'Alboran-Kabylia collage') and to the coeval opening of the Algerian basin. We find several offshore markers of the boundary between the Internal Zones deriving from the AlKaPeCa microcontinent and the External and flysch domains, and propose a transition to the newly formed deep basin using bathymetry and magnetic anomalies. This allows us to infer that Internal Zones constitute the basement of most of the margin from Dellys to $\mathrm{E} 0^{\circ} 10^{\prime}$, getting narrower from east to west (from $\sim 100 \mathrm{~km}$ to $\sim 30 \mathrm{~km}$ ), and then disappearing at the place where the margin changes strike (Fig. 6). Our observations in the Oran area are in line with several tectonic models [27,30,43] favouring a strong westward translation of the Alboran terrane, shaping the northern and southern margins of the East Alboran sea as transform segments through a westward rollback process. Active folding and faulting is widespread mostly at the outer and inner limits of the Internal Zones. Some old structures, inherited from the Miocene, certainly contributed to the current morphology of the margin. The steep margin between Arzew and El Marsa illustrates this former activity. In the present day NW-SE stress field, during the Plio-Quaternary, new structures were formed, like the important east-west or NE-SW faults and folds around Algiers. The location of the seismic activity in the process of tectonic inversion of the margin is not necessarily around the old sutures. For instance, in the case of the former transform margin in the Oran region, the present deformation is located in the Cheliff area, further inland. Furthermore, the Plio-Quaternary tectonic style is totally different from the one during the Miocene. For instance, strike-slip activity along NW-SE or east-west structures appears to be weak or absent, whereas reverse dip-slip faulting dominates.

The interpretation of the geological nature of the basement proposed in this paper is only preliminary. We acknowledge that several questions remain open concerning the exact nature, extent and structure of the offshore domain: for instance, whether or not large strike-slip zones (part or not of large pull-apart basins [38]) torn the Internal Zones apart during their drift, or bookshelf faulting [42] plays a role in the last stages of deformation, cannot be assessed from our observations alone. Some other uncertainties still remain: for instance, the exact Internal/External Zones boundary between Tenes and Chenoua probably lies in the coastal zone, but is not properly 
depicted because not fully covered during our survey. Further cruises are therefore needed to complement this mapping, especially near the coastline. Sampling of the basement through coring, dredging and diving is also necessary in order to better assess our interpretation in most areas. It could for instance lead to a better understanding of the role played by the Yusuf ridge in the tectonic evolution of the area of Oran. Finally, future studies of the gravimetry and magnetic data, together with deep seismic sections, should also provide important insights on the transition from Internal Zones to the basement of the Algerian basin.

\section{Acknowledgements}

We wish to thank IFREMER and the crew of the R/V Le Suroit, led by Captain A. Werly for their support during the Maradja cruise. Thanks to R. Cagna for efficient and continuous onboard processing. This research was funded by the French ACI (Action concertée incitative) 'Risques naturels' programme ('Action spécifique Algérie'), ESF EUROMARGINS Programme (01-LEC-EMA22F Westmed Project) through 'GDR Marges' ('Instabilités gravitaires'), and the French-Algerian CMEP Project TASSILI No. 041MDU619. We are indebted to SHFN ('Service hydrographique des forces navales', Algeria) and to the Algerian State for allowing this study. We also thank D. Frizon de Lamotte, A. Boudiaf and J.-P. Gélard for helpful comment on the manuscript. Contribution No. 974 of the IUEM, European Institute for Marine Studies (Brest, France). Contribution No. 2087 of GDR 'Marges'.

\section{References}

[1] J. Acosta, M. Canals, J. López-Martínez, A. Muñoz, P. Herranz, R. Urgeles, C. Palomo, J.L. Casamor, The Balearic Promontory geomorphology (western Mediterranean): morphostructure and active processes, Geomorphology 49 (3-4) (2003) 177-204.

[2] M.O. Aïte, Paléocontraintes post-collision identifiées dans le Néogène de Grande Kabylie (Algérie), C. R. Acad. Sci. Paris, Ser. IIa 320 (1995) 433-438.

[3] M.O. Aïte, J.-P. Gélard, Distension néogène post-collisionnelle sur le transect de Grande-Kabylie (Algérie), Bull. Soc. géol. France 168 (4) (1997) 423-436.

[4] B. Alonso, G. Ercilla, Small turbidite systems in a complex tectonic setting (SW Mediterranean Sea): morphology and growth patterns, Mar. Pet. Geol. 19 (10) (2002) 1225-1240.

[5] J. Aubouin, M. Durand-Delga (Eds.), Aire méditerranéenne, Encyclopaedia universalis, vol. 10, 1971, pp. 743745.

[6] R. Augier, L. Jolivet, C. Robin, Late Orogenic doming in the Eastern Betics: Final exhumation of the NevadoFilabride complex and its relation to basin genesis, Tectonics 24 (4) (2005) TC4003, doi:10.1029/2004TC001687.

[7] J.-M. Auzende, J. Bonnin, J.-L. Olivet, The origin of the western Mediterranean Basin, J. Geol. Soc. Lond. 129 (1973) 607-620.

[8] A. Ayadi, S. Maouche, A. Harbi, M. Meghraoui, H. Beldjoudi, F. Oussadou, A. Mahsas, D. Benouar, A. Heddar, Y. Rouchiche, A. Kherroubi,M. Frogneux, K. Lammali, F. Benhamouda, A. Sebaï, S. Bourouis, P.J. Alasset, A. Aoudia, Z. Cakir, M. Merahi, O. Nouar, A. Yelles, A. Bellik, P. Briole, O. Charade, F. Thouvenot, F. Semmane, A. Ferkoul, A. Deramchi, S.A. Haned, Strong Algerian earthquake strikes near capital city, EOS Trans. AGU 84 (50) (2003) 561-568.

[9] M. Bezzeghoud, E.R. Buforn, Source parameters of the 1992 Melilla (Spain, $M w=4.8$ ), 1994 Alhoceima (Morocco, $M w=5.8$ ) and 1994 Mascara (Algeria, $M w=5.7$ ) earthquakes and seismotectonic implications, Bull. Seismol. Soc. Am. 89 (1999) 359-372.

[10] A Boudiaf, Étude sismotectonique de la région d'Alger et de la Kabylie (Algérie), thèse d'État, Montpellier, 1996, $274 \mathrm{p}$.

[11] A. Boudiaf, H. Philip, A. Coutelle, J.-F. Ritz, Découverte d'un chevauchement d'âge Quaternaire au sud de la Grande Kabylie (Algérie), Geodin. Acta 12 (2) (1999) 71-80.

[12] J.-P. Bouillin, Le bassin maghrébin : une ancienne limite entre l'Europe et l'Afrique à l'Ouest des Alpes, Bull. Soc. géol. France 8 (4) (1986) 547-558.

[13] J.-P. Bouillin, La répartition des affleurements de la Dorsale kabyle: héritage d’une segmentation mésozoïque de la marge nord-téthysienne ?, C. R. Acad. Sci. Paris, Ser. II 315 (1992) 1127-1132.

[14] J.-P. Bouillin, M. Durand-Delga, P. Olivier, Betic-Rifian and Tyrrhenian Arcs: Distinctive features, genesis and development stages, in: F.C.Wezel (Ed.), The Origin of Arcs, Dev. Geotectonics 21 (1986) 281-304.

[15] J.-C. Bousquet, Quaternary strike-slip faults in southeastern Spain, Tectonophysics 52 (1979) 277-286. 
[16] E. Calais, C. DeMets, J.-M. Nocquet, Evidence for a post-3.16 Ma change in Nubia-Eurasia plate motion, Earth Planet. Sci. Lett. 216 (2003) 81-92, doi:10.1016/S0012-821X(03)00482-5.

[17] E. Carminati, M.J.R.Wortel,W. Spakman, R. Sabadini, The role of slab detachment processes in the opening of the westerncentral Mediterranean basins: some geological and geophysical evidence, Earth Planet. Sci. Lett. 160 (1998) 651-665.

[18] W. Cavazza, F.M. Roure, W. Spakman, G.M. Stampfli, P.A. Ziegler (Eds.), The Transmed Atlas - The Mediterranean Region from Crust to Mantle, Springer, Berlin, Heidelberg, 2004.

[19] A. Chalouan, A. Michard, The Alpine Rif Belt (Morocco): a case of Mountain Building in a SubductionSubduction-Transform Fault Triple Junction, Pure Appl. Geophys. 161 (2004) 489-519.

[20] M.C. Comas, J.P. Platt, J.I. Soto, A.B. Watts, The origin and tectonic history of the Alboran basin: insights from Leg 161 results, in: R. Zahn, M.C. Comas, A. Klaus (Eds.), Proc. ODP, Sci. Results 161 (44) (1999) 555-580.

[21] B. Delouis, M. Vallée, M. Meghraoui, E. Calais, S. Maouche, K. Lammali, A. Mahsas, P. Briole, F. Benhamouda, K. Yelles, Slip distribution of the 2003 Boumerdes-Zemmouri earthquake, Algeria, from teleseismic, GPS, and coastal uplift data, Geophys. Res. Lett. 31 (2004) L18607, doi:10.1029/2004GL020687.

[22] J. Déverchère, K. Yelles, A. Domzig, B. Mercier de Lépinay, J.-P. Bouillin, V. Gaullier, R. Bracène, E. Calais, B. Savoye, A. Kherroubi, P. Le Roy, H. Pauc, G. Dan, Active thrust faulting offshore Boumerdes, Algeria, and its relations to the $2003 \quad M w 6.9$ earthquake, Geophys. Res. Lett. 32 (2005) L04311, doi:10.1029/2004GL021646.

[23] S. Duggen, K. Hoernle, P. van den Bogaard, C. Harris, Magmatic evolution of the Alboran region: The role of subduction in forming the western Mediterranean and causing the Messinian Salinity Crisis, Earth Planet. Sci. Lett. 218 (2004) 91-108.

[24] M. Durand-Delga, Mise au point sur la structure du Nord-Est de la Berbérie, Publ. Serv. géol. Algérie 39 (1969) 89-131.

[25] M. Durand-Delga, J.M. Fonboté, Le cadre structural de la Méditerranée occidentale, in: J. Aubouin, J. Debelmas, M. Latreille (Eds.), Géologie des chaînes alpines issues de la Téthys, Colloque no 5, 26e Congrès géologique international, Paris, in: Mém. BRGM, 1980, pp. 67-85.

[26] M. El Robrini, M. Genesseaux, A. Mauffret, Le séisme d'El Asnam (Algérie) 1980 et l'instabilité des pentes algériennes, Rapp. Comm. Int. Mer Médit. 29 (2) (1985) 113-114.

[27] D. Frizon de Lamotte, B. Saint Bezar, R. Bracène, E. Mercier, The two main steps of the Atlas building and geodynamics of the western Mediterranean, Tectonics 19 (4) (2000) 740-761.

[28] A. Galdeano, J.-C. Rossignol, Assemblage à altitude constante de cartes d'anomalies magnétiques couvrant l'ensemble du bassin occidental de la Méditerranée, Bull. Soc. géol. France 7 (1977) 461-468.

[29] B. Gelabert, F. Sabat, A. Rodriguez-Perea, A new proposal for the Late Cenozoic geodynamic evolution of the western Mediterranean, Terra Nova 14 (2002) 93-100.

[30] M.-A. Gutscher, J. Malod, J.-P. Réhault, I. Contrucci, F. Klingelhöfer, L. Mendes-Victor, W. Spakman, Evidence for active subduction beneath Gibraltar, Geology 30 (2002) 1071-1074.

[31] D. Hatzfeld, Etude sismotectonique de la zone de collision Ibéromaghrébine, thèse d'État, Grenoble, 1978, 281 p.

[32] J.V.A. Keller, S.H. Hall, C.J. Dart, K.R. McClay, The geometry and evolution of a transpressional strike-slip system: the Carboneras fault SE Spain, J. Geol. Soc. Lond. 152 (1995) 339-351.

[33] M. Kieken, Esquisse tectonique de l’Algérie, Publ. de la Carte Géol., Alger, 31, 1962, 16 p.

[34] L. Jolivet, C. Faccenna, Mediterranean extension and the Africa-Eurasia collision, Tectonics 19 (6) (2000) 1095-1106.

[35] D. Leblanc, P. Olivier, Role of strike-slip faults in the Betic-Rifian orogeny, Tectonophysics 101 (1984) 345355.

[36] L. Leclaire, Plateau continental nord-africain : nature de la couverture sédimentaire actuelle et récente, thèse d'État, Paris, 1970, 391 p.

[37] L. Lonergan, N. White, Origin of the Betic-Rif mountain belt, Tectonics 16 (1997) 504-522.

[38] A. Mauffret, M. El-Robrini, M. Gennesseaux, Indice de la compression récente en mer Méditerranée : un bassin losangique sur la marge nord-algérienne, Bull. Soc. géol. France 8 (6) (1987) 1195-1206.

[39] A. Mauffret, D. Frizon de Lamotte, S. Lallemant, C. Gorini, A. Maillard, E-W opening of the Algerian Basin (Western Mediterranean), Terra Nova 16 (2004) 257-264.

[40] S. McClusky, R. Reilinger, S. Mahmoud, D. Ben Sari, A. Tealeb, GPS constraints on Africa (Nubia) and Arabia plate motions, Geophys. J. Int. 155 (2003) 126-138.

[41] M. Meghraoui, Blind reverse faulting system associated with the Mont Chenoua-Tipaza earthquake of 29 October 1989 (northcentral Algeria), Terra Nova 3 (1990) 84-93. 
[42] M. Meghraoui, J.-L. Morel, J. Andrieux, M. Dahmani, Tectonique plio-quaternaire de la chaîne tello-rifaine et de la mer d'Alboran. Une zone complexe de convergence continent-continent, Bull. Soc. géol. France 167 (1) (1996) 141-157.

[43] A. Michard, A. Chalouan, H. Feinberg, B. Goffé, R. Montigny, How does the Alpine belt end between Spain and Morocco?, Bull. Soc. géol. France 173 (1) (2002) 3-15.

[44] S. Migeon, B. Savoye, E. Zanella, T. Mulder, J.-C. Faugères, O. Weber, Detailed seismic-reflection and sedimentary study of turbidite sediment waves on the Var Sedimentary Ridge (SE France): significance for sediment transport and deposition and for the mechanisms of sediment-wave construction, Mar. Pet. Geol. 18 (2001) 179-208.

[45] J.-L. Morel, M. Meghraoui, Gorringe-Alboran-Tell tectonic zone: A transpression system along the AfricaEurasia plate boundary, Geology 24 (1996) 755-758.

[46] A.M. Negredo, P. Bird, C. Sanz de Galdeano, E. Buforn, Neotectonic modeling of the Ibero-Maghrebian region, J. Geophys. Res. 107 (B11) (2002) 2292, doi:10.1029/2001JB000743.

[47] J.-M. Nocquet, E. Calais, Geodetic Measurements of Crustal Deformation in the Western Mediterranean and Europe, Pure Appl. Geophys. 161 (2004) 661-681.

[48] J.-L. Olivet, J. Bonnin, P. Beuzart, J.-M. Auzende, Cinématique des plaques et paléogéographie: une revue, Bull. Soc. géol. France 7 (1982) 875-892.

[49] G. Pautot, Cadre morphologique de la Baie des Anges. Modèle d'instabilité de pente continentale, Oceanol. Acta 4 (1981) 203-212.

[50] D. Raymond, Évolution sédimentaire et tectonique du Nord-Ouest de la Grande Kabylie (Algérie) au cours du cycle alpin, thèse d’État, université Paris-6, 1976, 152 p.

[51] L.E. Ricou, Tethys reconstructed: plates, continental fragments and their boundaries since 260 Ma from Central America to South-eastern Asia, Geodin. Acta 7 (1994) 169-218.

[52] E. Roca, D. Frizon de Lamotte, A. Mauffret, R. Bracène, J. Vergès, N. Benaouali, M. Fernandez, J.A. Munoz, H. Zeyen, TRANSMED Transect II, in: W. Cavazza, F.M. Roure, W. Spakman, G.M. Stampfli, P.A. Ziegler (Eds.), The Transmed Atlas - The Mediterranean Region from Crust to Mantle, Springer, Berlin, Heidelberg, 2004.

[53] D. Stich, C.J. Ammon, J. Morales, Moment tensor solutions for small and moderate earthquakes in the IberoMaghreb region, J. Geophys. Res. 108 (B3) (2003) 2148, doi:10.1029/2002JB002057.

[54] G. Thomas, Mise en évidence de décrochements dextres est-ouest d'âge Quaternaire en Algérie nordoccidentale, C. R. Acad. Sci. Paris, Ser. D 283 (1976) 893-896.

[55] W. Wildi, La chaîne tello-rifaine (Algérie, Maroc, Tunisie): Structure, stratigraphie et évolution du Trias au Miocène, Rev. Géol. Dyn. Géogr. Phys. 24 (1983) 201-297.

[56] WCC (Woodward Clyde Consultants): 1984, Seismic microzonation of Ech-Cheliff region, Algeria. Report prepared for C.T.C., Algiers, 1, CTC, Algeria, 145 p.

[57] K. Yelles, M. Derder, H. Djellit, A. Abtout, A. Boudiaf, Seismicity of the Algerian margin: origin and consequences, in: Proc. ${ }^{\text {st }}$ Int. Symp. Geophysics, Tanta, Egypt, 1999, pp. 245-252. 